\title{
内分泌かく乱物質によるプロゲステロン作用のかく乱
}

徳 元 俊 伸 (静岡大 ·理 ·生物) sbttoku@ipc.shizuoka.ac.jp

内分泌かく乱物質がそのエストロゲン様作 用あるいは抗エストロゲン作用により生殖系 に悪影響を与えることはいまさら紹介すべき 内容ではないであろう。“メス化する自然” いう言葉に象徴されるように、内分泌かく乱 物質のホルモン作用により本来オスであるは ずの個体の生殖巣が精巣にならずに卵巣へと 分化してしまうという作用は非常に印象的で あり、一般には内分泌かく乱物質(環境ホル モン)の作用といえばエストロゲン作用のか く乱を意味しているといっていいだろう。し かし我々が行なった魚類卵成熟の研究により、 内分泌かく乱物質がプロゲステロン作用のか く乱も引き起こすことが明らかになった。

\section{1. 卵成熟誘起に及ぼす内分泌かく乱物質の影} 響：卵成熟誘起作用を持つ物質が存在した！

魚類卵母細胞はいったん減数分裂を停止し た状態で成長し、産卵の直前に減数分裂を完 了、その後、濾胞細胞層から解離 (排卵) し、 産み出される(図1)。魚類卵の最終成熟は、 LHの働きにより卵濾胞組織でつくられるス テロイド性の卵成熟誘起ホルモン (キンギョ やゼブラフィッシュでは $17 \alpha, 20 \beta-$ dihydroxy-4pregnen-3-one,17,20ß-DHP と考えられている) の作用により誘起される。しかし、この17,20 $\beta$-DHPは、通常のステロイドホルモンとは異
なり、卵表に局在すると考えられるステロイ ド膜受容体に結合して、遺伝子発現の誘導を 介さないノンゲノミックな反応により作用す ると考えられている。図2に魚類卵成熟誘起

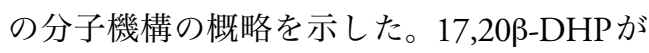
ステロイド膜受容体に結合することにより、 卵細胞内の cAMP 濃度の減少 $\rightarrow$ サイクリン B タンパク質の翻訳 $\rightarrow \mathrm{cdc} 2$ のリン酸化が順次起 こり、その結果卵成熟促進因子 (MPF) が活性 化され卵核胞が崩壊 (GVBD) して、卵は成熟 する ${ }^{1)}$ 。魚類卵の場合、卵成熟に伴い卵の透 明化が起こる。我々が通常、実験に用いてい るキンギョやゼブラフィッシュではこの透明 化を実体顕微鏡下で観察することによっても 卵成熟が容易に判定できる。卵成熟のインビ トロ培養実験は卵巣を摘出して未成熟卵を分 離し、これらに各種物質を作用させて培養す るという単純なものであるが、個体差はある ものの細胞周期の停止状態にある卵を用いる ことから同調性に極めて優れている。

我々はこの卵の培養系を用いて種々の内分 泌かく乱物質について魚類の卵成熟誘起作用、 あるいは天然の卵成熟誘起ホルモンである 17,20ß-DHPの卵成熟誘起作用に対する阻害 効果について調べた (図3)。その結果、試み た内分泌かく乱物質のうちで、ジエチルスチ

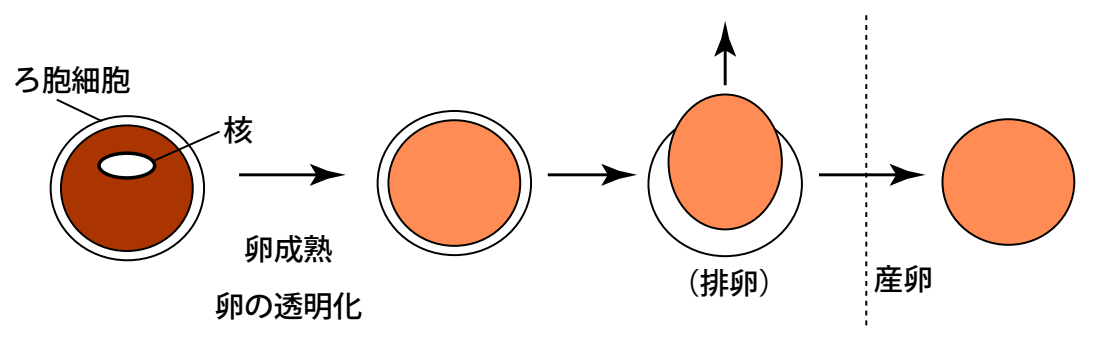

図1 魚類の卵成熟と排卵 


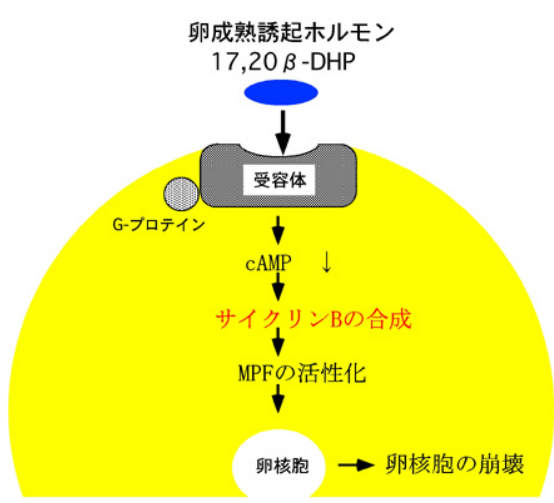

図2 魚類卵成熟誘起の分子メカニズム

ルベストロール (DES) が、単独で強い卵成 熟誘起作用を持つことを発見した(図4)。ま た、このDESで誘起される卵成熟は、17,20 $\beta$-DHPで誘起される卵成熟の場合と同様に、 MPFの活性化を介して誘起されていること が確認された2)。DESは環境ホルモンを世に 広めた『奪われし未来』に度々登場する合成 エストロゲンであり、強いエストロゲン活性 を持つ物質である。これが流産防止等の目的 で妊婦に投与されていたが、それが癌の発症

誘起作用

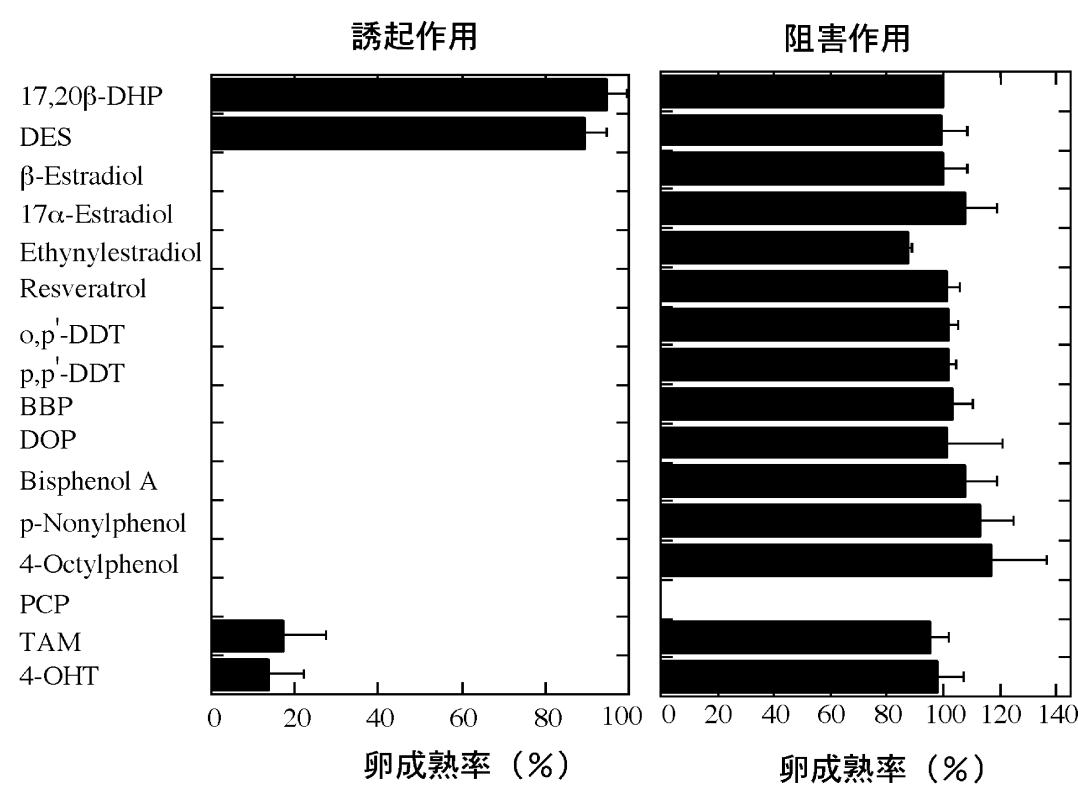

や胎児に生殖器官の形成異常などをもたらす ことが後に明らかになり、使用が禁止された 物質である。この物質が卵成熟誘起作用を持 つという我々の結果は予想外の驚くべき結果 であった。なぜなら卵成熟はプロゲステロン 類により誘起される反応であり、エストロゲ ンは全く効果が無いか、むしろ阻害効果をも たらす場合も報告されていたからである。キ ンギョやゼブラフィッシュでもエストロゲン 類は卵成熟誘起に全く効果が無かった。そこ で、この予想外であったDESの卵成熟誘起 作用を解明するため、作用に必要な構造や作 用機構について解析を進めた。

\section{2. 卵成熟誘起作用を示す化学構造につい て :DESの誘導体を用いた解析}

DESは薬品として生産されていたことか ら様々な誘導体が合成されている。そこでこ れら誘導体を用いてDESのホルモン作用に 必要な化学構造の同定を目指し、誘導体群の 構造と卵成熟誘起活性の関係を調べた(図5)。 その結果、DESのエチル基をメチル基に置

図3 内分泌かく乱物質によるゼブラフィッシュ卵成熟の誘起と阻害 各物質の卵成熟誘起作用についてはそれぞれの物質を $1 \mu \mathrm{M}$ の濃度で作用させて卵成熟率を求

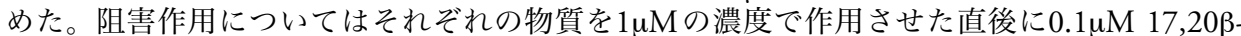
DHPを作用させて卵成熟率を求めた。阻害作用の場合の卵成熟率は $0.1 \mu \mathrm{M} 17,20 \beta-D H P に よ$ る誘起率を $100 \%$ とした場合の相対值で示してある。 


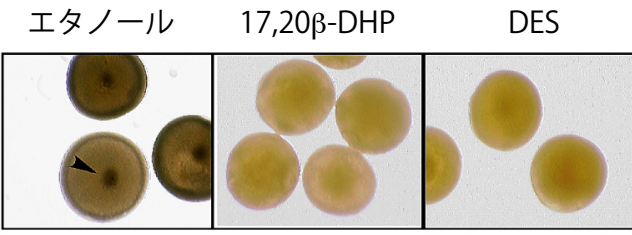

図4 DESによるキンギョ卵成熟の誘起 キンギョ卵にホルモン類の溶媒であるエ夕ノー ル、DES 又は $17,20 \beta-\mathrm{DHP}$ を作用させ、6時間培 養した。培養後の卵に透明化処理を行って撮影 した。エ夕ノール処理群では矢尻で示した卵核 胞が残つているが17,20ß-DHP、DES処理群で は卵成熟を起こした結果、卵核胞が消失している。

換したDMSでは作用は極端に小さくなった が、中央の二重結合の部位の誘導体 (HEX、 DIES) についてはやや効果は低くなったも のの卵成熟誘起活性を示した。また、DES の両端の水酸基を化学修飾した、DM-DES、 DP-DESの場合は卵成熟の誘起活性が極めて 低いことが明らかになった。これらの結果か ら、DESの標的分子との結合にはエチル基

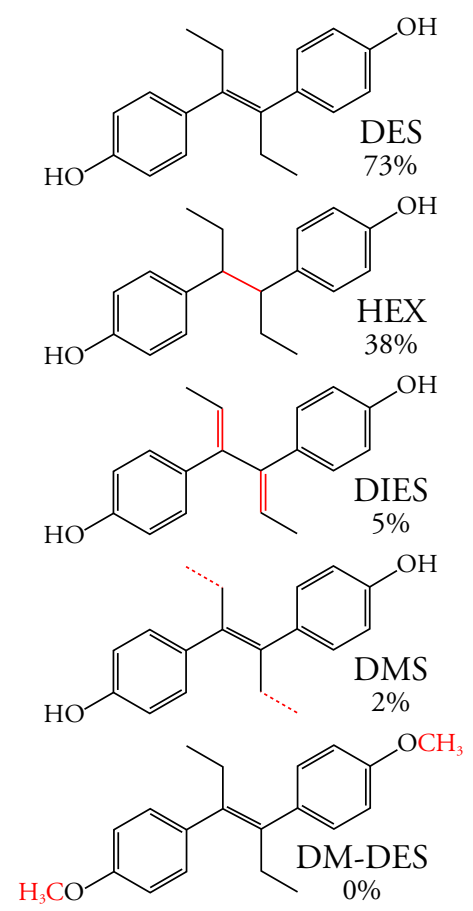

図5 DES 誘導体の卵成熟誘起活性の比較 各誘導体の化学構造とそれぞれを $1 \mu \mathrm{M}$ の濃度で 作用させた場合の卵成熟率を示した。DES と構 造の違う部分を赤で示している。
と両端の水酸基の両方が必要であることが分 かった。また、HEXとDIESの作用濃度にお よそ10倍の差がみられたことからエチル基 の回転自由度が標的分子との相互作用には重 要であることが明らかになった。

DESの両端の水酸基が受容体との結合に おいて 17,20 $\beta$-DHPの水酸基や3位の酸素原 子と類似の役割を果たしていることは、分子 軌道計算による最小エネルギーコンフォメ ーションの推定結果からも支持された。軌道 計算によるとDESは多様な立体構造を取り 得ることが明らかになったが、17,20 とDESの最小エネルギーコンフォメーショ ンの何通りかは両分子の両端の酸素原子の 原子間距離がよく一致した。このことから DESの両端の水酸基が受容体との結合に関 与していると推定される。

DESの誘導体を用いたこれらの実験から 卵成熟誘起作用を示す化学構造の一つが明ら かになった。そこで、このような構造をもつ 物質を検索したところ夕モキシフェン類がみ つかつた。タモキシフェン類についても卵成 熟誘起活性を調べたところ、低いながらも卵 成熟を直接誘起する活性がみられた（図3）。 この結果から、エチル基のついたスチルベン 構造が卯成熟誘起の標的分子との相互作用に 必要であることが推察できる3)。

\section{DESの作用機構：ステロイド膜受容体分 子 (mPR) の同定}

DESの作用機構を推定するためにまず、 DESにより誘起される卵成熟と天然の卵成 熟誘起ホルモンである17,20 成熟の時間経過を比較した。その結果、双方 に大きな差がみられなかったことから DES

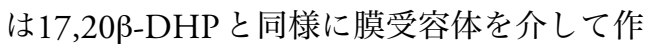
用すると推定された。さらに、DESの標的 分子がステロイド膜受容体であることを調べ るため、DES と 17,20 $\beta$-DHP との共培養実験 を行なった。その結果、DES、17,20ß-DHP のそれぞれが単独では卵成熟を誘起できない 濃度を同時に作用させることで卵成熟を誘 
起することが明らかとなり、両者の共同作 用がみられたことから、DESの標的分子が 同じ膜受容体であることが示唆された。この ことから DES はステロイド膜受容体に作用 することが強く示唆された。こうして我々が DESの作用について研究を進めている最中、 長年追い求められていた卵膜のステロイド膜 受容体分子がついに同定されたとの衝撃的な 内容の論文が発表された。

冒頭に紹介したように卵成熟誘起における プロゲステロン類の作用は膜表面にある受容 体を介したものであることが25年前に示さ れ、その後、卵の膜画分にプロゲステロン類 が結合することが確かめられていたが実体は つかめないままであった。しかし、ついにそ の遺伝子配列がテキサス大学の P. Thomas ら によって報告されたのであった4)。早速我々 も、DESの標的分子の最有力候補であるス テロイド膜受容体遺伝子 $(\mathrm{mPR})$ のキンギョ ホモログ遺伝子のクローニングを開始した。 $\mathrm{mPR}$ には $\alpha, \beta 、 \gamma$ 3夕イプが存在することが ヒトやマウスのゲノム情報より明らかにされ ていたが、キンギョ卵巣 cDNAライブラリ 一のスクリーニングの結果、キンギョ卵巣に は $\alpha 、 \beta$ の他、 $\gamma$ にいては2夕イプ $(\gamma-1 、 \gamma-2)$ 、 計4夕イプが存在することが明らかになつた。 我々はまず、そのうち $\mathrm{mPR}$ そのものとして 最初に同定された $\alpha$ タイプについて機能解析 を進めた。 $\mathrm{mPR} \alpha$ はそのアミノ酸配列から7 回膜貫通型の膜タンパク質であることが予測 されている。そこで、 $\mathrm{N}$ 末端の細胞外領域、 中央の細胞外領域の GST 融合リコンビナン トタンパク質を発現し、抗体を作製した。そ の結果、 $\mathrm{N}$ 末端の細胞外領域、中央の細胞外 領域を抗原にした場合に目的の $\mathrm{mPR} \alpha$ と推 定される $40 \mathrm{kDa}$ のバンドと反応する抗体が 得られた。この抗体を用いた解析で、卵の卵 成熟誘起能と $\mathrm{mPR} \alpha$ タンパク質の発現量に 相関がみられたことや、モルフォリノアンチ センスオリゴヌクレオチドの卵内への微少注 入によるノックダウン実験から卵成熟の阻害 率と $\mathrm{mPR} \alpha$ タンパク質の減少が一致してみ
られたことから mPRaがキンギョステロイ ド膜受容体の一つであることが示唆された5)。 そこでステロイドホルモンとの相互作用部位 である可能性の高い、 $\mathrm{mPR} \alpha \mathrm{N}$ 末端の細胞外 領域に対するポリクローナル抗体の卵成熟誘 起に対する阻害効果を調べた。その結果、こ の抗体を作用させた卵では17,20及-DHPによ る卵成熟誘起が阻害された他、DESによる

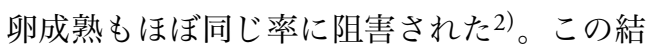
果は $\mathrm{mPR} \alpha$ がステロイド膜受容体であるこ とを示すと同時にDESの標的分子が $\mathrm{mPR} \alpha$ であることを強く支持する。

\section{4. 卵成熟誘起に及ぼす内分泌かく乱物質の 影響: 卵成熟誘起阻害作用を持つ物質が存在 した}

一方、十数種類の内分泌かく乱物質につい て卵成熟誘起に対する阻害作用を示すかどう かについても検討した (図3) 3 )。その結果、 各物質を17,20ß-DHP と同時に添加した場合、 他の物質がほとんど作用を示さなかったのに 対してペンタクロロフェノール (PCP) のみ が極めて高い阻害活性を示し、卵成熟を完全 に阻害した。PCPは農薬の成分として使用 されていた物質である。また、内分泌かく乱 物質により卵を前処理した場合にはメトキシ クロルと PCPが阻害活性を示した。メトキ シクロルは前処理した場合に卵成熟を阻害す ることがアフリカツメガエルで既に報告され ていたが、サカナでも同様の結果となった。 同時添加では阻害活性がみられなかったこと からこの物質の場合は卵内に浸透し、ステロ イド膜受容体以降のシグナル伝達経路を阻害 するものと推定される。これに対して PCP は17,20ß-DHP と同時添加の場合も作用する ことからステロイド膜受容体に作用している 可能性が高い。図6に我々のこれまでの実験 において効果のみられた物質の構造式を示し た。PCPの阻害効果は $17,20 \beta-D H P 、 D E S そ$ してタモキシフェンによる卵成熟全てに対し てみられた。このことはこれらの物質が同じ 経路に作用していることを示唆している。 
<smiles>CCC(=C1C=CC(O)CC1)C(CC)c1ccc(O)cc1</smiles>

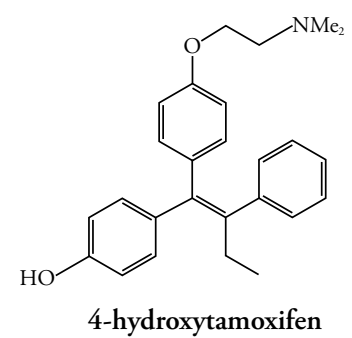<smiles>Clc1c(Cl)c(Cl)c(Cl)c(Cl)c1Cl</smiles>

PCP<smiles>COc1ccc(C(c2ccc(OC)cc2)C(Cl)(Cl)Cl)cc1</smiles>

Methoxychlor

図6 魚類卵成熟に影響を及ぼす物質の構造

\section{5. 生体内実験系の確立一内分泌かく乱物質 はin vivoにおいても卵成熟をかく乱する一}

一方、ステロイドホルモンや内分泌かく乱 物質を飼育水に直接に添加し、サカナの生体 そのものに作用させる実験を試みたところ、 DESがin vivoにおいても実際に卵成熟誘起 活性を示すことが明らかになった。ゼブラ フィッシュにおいてはin vivoにおいてもin vitro と同様、3 時間程度で卵成熟が誘起され た。また、卵成熟に対して強い阻害作用を示 すことが明らかになった PCPについても in vitro と同様にin vivoにおいても卵成熟阻害 作用を示すことが明らかになった。

\section{6. 今後の展望}

ステロイドホルモンの受容体としては核内
受容体が古くから同定され、一般にステロイ ドホルモンは核内受容体を介して作用するも のと考えられてきた。しかし、卵成熟誘起に おいてはステロイドホルモンは核内受容体で はなく細胞膜表面のステロイド膜受容体を介 して作用することが提唱され、ついにその候 補遺伝子が発見された。発見された受容体候 補遺伝子は卵だけではなく、そのサブタイプ を含めると脳や腎臓をはじめ、あらゆる組織 で発現していることが明らかになった。この ことから細胞膜表面のステロイド受容体を介 したシグナル伝達経路が卵成熟だけではなく 一般的なステロイドの作用機構の一つである と考えられ、今後その構造・機能の解明に向 けて多くの研究が進められるものと予想され る。本研究で開始した卵膜のステロイド膜受 容体分子の機能解析をさらに進め、この新規 分子の機能解明に貢献できればと考えている。

我々の発見したDESのプロゲステロン様 作用、PCPの強い卵成熟阻害作用について も内分泌かく乱物質の抗プロゲステロン作 用として新しい知見である。今後、DESや PCP とこの新規ステロイド膜受容体との関 連について、受容体との結合実験などにより 詳細に検討する予定である。

1 ) Nagahama Y, Yoshikuni M, Yamashita M, Tokumoto T, Katsu Y. (1995) Curr Top Dev Biol 30: 103-145.

2 ) Tokumoto T, Tokumoto M, Horiguchi R, Ishikawa K, Nagahama Y. (2004) Proc Natl Acad Sci USA 101: 3686-3690.

3 ) Tokumoto T, Tokumoto M, Nagahama Y. (2005) Reprod Biol Endocrinol 3: 69.

4 ) Zhu Y, Rice CD, Pang Y, Pace M, Thomas P. (2003) Proc Natl Acad Sci USA 100: 2231-2236.

5 ) Tokumoto M, Nagahama Y, Thomas P, Tokumoto T. (2006) Gen Comp Endocrinol 145: 101-108. 